\title{
Calcium hydroxide removal: Effectiveness of ultrasonic and manual techniques
}

\author{
Remoção de hidróxido de cálcio: Eficácia das técnicas \\ ultrassônica e manual
}

\begin{abstract}
Purpose: Different techniques have been proposed to improve the removal of calcium hydroxide. The purpose of this in vitro study was to compare the effectiveness of ultrasound and manual techniques in the removal of calcium hydroxide from root canals.

Methods: Thirty-eight single-rooted teeth were divided into two groups of 19 teeth each. The teeth were prepared using the crown-down technique with an apical master file \#50. After shaping, the canals were radiographed and dressed with calcium hydroxide. After 14 days, the calcium hydroxide was removed with the ultrasound technique in group I and through manual filing in group II. The teeth were then radiographed again to evaluate the removal of the paste. To assess the calcium hydroxide removal, the radiographs were scanned and analyzed based on the gray levels. The independent samples and Student's t-tests $(\alpha=0.05)$ were used for each group to compare the efficacy of calcium hydroxide removal between the groups and among thirds (cervical, middle and apical).

Results: There was no difference between ultrasound and manual techniques in the removal of calcium hydroxide from root canals. There were no statistical differences among the thirds analyzed.

Conclusion: Neither manual nor ultrasonic techniques completely removed calcium hydroxide from the root canal.
\end{abstract}

Key words: Endodontics; calcium hydroxide

\section{Resumo}

Objetivo: Diferentes técnicas são propostas para melhorar a remoção da pasta de hidróxido de cálcio. $O$ objetivo do presente estudo in vitro foi comparar a efetividade das técnicas ultrassônica e manual para a remoção do hidróxido de cálcio do canal radicular.

Metodologia: Trinta e oito dentes monorradiculares foram divididos em dois grupos de 19 dentes cada. Os dentes foram preparados através da técnica de coroa-ápice até o instrumento memória \#50. Após o preparo, os canais foram radiografados e, então, preenchidos com hidróxido de cálcio. A remoção da pasta no grupo I foi feita com o uso do ultrassom enquanto que no grupo II, a pasta foi removida através da técnica manual. Os dentes foram radiografados novamente para avaliar a remoção do hidróxido de cálcio. As radiografias foram digitalizadas e os terços avaliados de acordo com os níveis de cinza para quantificar a remoção do hidróxido de cálcio. Os testes para amostras independentes e o † de Student $(\alpha=0.05)$ foram aplicados para comparar a remoção da pasta entre os grupos e entre os terços do canal.

Resultados: Não houve diferença entre as técnicas ultrassônica e manual para a remoção do hidróxido de cálcio do canal radicular. Não houve diferenças estatísticas na comparação ente os terços avaliados.

Conclusão: Nem a técnica manual nem a ultrassônica removeram completamente o hidróxido de cálcio do canal radicular.

Palavras-chave: Endodontia; hidróxido de cálcio; ultrassom

\section{Daiana Elisabeth Böttcher a \\ Nicole de Mello Rahde b \\ Fabiana Soares Grecca a}

- School of Dentistry, Federal University of Rio Grande do Sul (UFRGS), Porto Alegre, RS, Brazil b School of Dentistry, Pontifical Catholic University of Rio Grande do Sul (PUCRS), Porto Alegre, RS, Brazil

\section{Correspondence:}

Fabiana Soares Grecca

Avenida Ramiro Barcelos, 2492

Porto Alegre, RS - Brazil

90035-003

E-mail: fabiana.grecca@ufrgs.br

Received: September 20, 2011

Accepted: June 29, 2012

Conflict of Interests: The authors state that there are no financial and personal conflicts of interest that could have inappropriately influenced their work.

Copyright: (c) 2011 Böttcher et al.; licensee EDIPUCRS. This is an Open Access article distributed under the terms of the Creative Commons AttributionNoncommercial-No Derivative Works 3.0 Unported License. 


\section{Introduction}

In endodontics, the use of intracanal dressing is important between treatment sessions for periapical periodontitis. Calcium hydroxide $(\mathrm{CH})$ has been used to inactivate bacterial LPS (1), to induce the formation of mineralized tissue (2) and to change the $\mathrm{pH}$ in the tubules through the diffusion of hydroxyl ions (3), thereby contributing to the success of endodontic therapy.

In order to maximize the properties of $\mathrm{CH}$, the pulp space should be filled with the medication (4-6). However, the removal of $\mathrm{CH}$ may be difficult, which raises questions regarding the appropriate method to use for the effective removal of the paste and the consequences of keeping the medication in the root canal filling (7-11). Different irrigating solutions and hand files have been widely used for this purpose $(8,10,12)$.

Several studies (13-15) have demonstrated the ability of ultrasound to promote greater root canal cleansing by removing the smear layer. However, its use in the removal of $\mathrm{CH}$ has shown different results depending on the paste vehicle or the irrigating solution used (16-18).

Thus, the aim of this in vitro study was to compare the effectiveness of ultrasound and manual techniques in removing $\mathrm{CH}$ from root canals.

\section{Methods}

This study (protocol number 17525) was approved by the Institutional Review Board and by the Research Ethics Committee of the School of Dentistry at the Federal University of Rio Grande do Sul (Brazil).

Thirty-eight human single-rooted teeth with fully formed apices and straight root canals were selected for this study. The teeth were stored in saline solution until they were used. Roots with cracks, caries, open apices, or resorptive defects were excluded from the study.

The coronal portions of the teeth were removed with diamond disks, standardizing the root length to $14 \mathrm{~mm}$. A diamond bur (KG Sorensen, Barueri, SP, Brazil) was used to gain straight-line access to the root canal. Using a syringe and a 27-gauge needle (Ultradent Products Inc., Indaiatuba, SP, Brazil), the canal was irrigated with $2 \mathrm{~mL}$ of a $2.5 \%$ sodium hypochlorite solution $(\mathrm{NaOCl})$ (Biodinâmica Química e Farmacêutica Ltda, Ibiporã, PR, Brasil) between each filing. A \#10 K-Flexofile (Dentsply Maillefer, Tulsa, OK, USA) was used to remove the pulp tissue and introduced further into the root canal until just the tip was visible at the apical foramen. The working length was determined by subtracting $1 \mathrm{~mm}$ from this length. The canal was instrumented using the crown-down technique from the working length up to a \#50 master apical file.

A final rinse with $3 \mathrm{~mL}$ of $17 \%$ EDTA (Biodinâmica, Ibiporã, PR, Brazil) and $2 \mathrm{~mL}$ of $2.5 \% \mathrm{NaOCl}$ was performed.

Radiographs (R1) were taken after the root canal preparation using Pró-70 (Prodental Equipamentos Odon- tológicos LTDA, Ribeirão Preto, SP, Brazil), which was operated at $70 \mathrm{kVp}$ and $8 \mathrm{~mA}$ with a focus-film distance of $40 \mathrm{~cm}$ and $0.4 \mathrm{~s}$ of exposure. Ultraspeed periapical film (Eastman Kodak Corp., Rochester, NY, USA) was used. The radiographs were processed during the same session, using an automatic method (DentX $9000^{\circledR}$, DentX, Elmsford, NY, USA) with new solutions and a cycle of 4.5 minutes. The root apices were sealed with sticky wax. The samples were dried and filled with $\mathrm{CH}$ (Calen, S.S. White Artigos Dentários Ltda., Rio de Janeiro, RJ, Brazil; Composition: $2.5 \mathrm{~g}$ calcium hydroxide, $0.5 \mathrm{~g}$ zinc oxide, $0.05 \mathrm{~g}$ colophony and $1.75 \mathrm{~mL}$ polyethylene glycol 400). The $\mathrm{CH}$ paste was placed using a threaded ML endodontic syringe (S. S. White Artigos Dentários Ltda., Rio de Janeiro, RJ, Brazil) with a 27-gauge needle (Terumo, Tokyo City, Tokyo, Japan). Radiographs were taken to evaluate the quality of the $\mathrm{CH}$ filling as previously described.

The access openings were sealed with a temporary filling material (Vigodent S/A Indústria e Comércio, Rio de Janeiro, RJ, Brazil). Teeth were stored in an incubator for 14 days at $37^{\circ} \mathrm{C}$ and $100 \%$ relative humidity. After this period, samples were randomly assigned to two groups.

For the utrasonic group (group 1, n=19), $\mathrm{CH}$ paste was removed using $2 \mathrm{~mL}$ of a $2.5 \% \mathrm{NaOCl}$ solution and ultrasonic activation was delivered for 1 minute using the Enac (Osada Electric Co, Tokyo City, Tokyo, Japan). The frequency of the oscilatting instrument (\#30 Flexofile) was fixed at $25 \mathrm{kHz}$. The activation was followed by a rinse with $3 \mathrm{~mL}$ of a $17 \%$ EDTA solution for 3 minutes. Canals were then dried with paper points.

For the manual group (group 2, n=19), $\mathrm{CH}$ paste was removed using $2 \mathrm{~mL} 2.5 \% \mathrm{NaOCl}$ with a \#30 Flexofile, which was placed through the working length and moved up for 1 minute. Manual removal was followed by $3 \mathrm{~mL} \mathrm{17 \%}$ EDTA for 3 minutes. Canals were then dried with paper points.

As previously described, radiographs were taken to evaluate the empty canals (R2).

The digitization of the radiographs was carried out using an Epson Perfection $2450^{\circledR}$ scanner (Epson, Long Beach, CA, USA) with a transparency adaptor. The images were captured in their original size, with $300 \mathrm{dpi}, 8$ bit mode, providing 256 grey levels. All radiographs were simultaneously captured. The images were exported to the Adobe Photoshop program (Adobe Systems Inc., San Jose, CA, USA). The canals were divided into cervical, middle and apical thirds and, using the histogram tool, the optical density of each third was recorded based on a scale of 256 possible shades of gray, with black representing zero and white representing 255 . The evaluation was performed by a calibrated examiner, and the Intraclass Correlation Coefficient (ICC) test revealed a good level of agreement (0.99).

Student's t-test was used to compare the gray values before and after $\mathrm{CH}$ dressing in each group. The independent sample test was used to compare the groups for each third. The confidence level was set at $5 \%$. 


\section{Results}

The gray values before and after $\mathrm{CH}$ dressing for each group are shown in Table 1. The results showed that after removing the $\mathrm{CH}$ from the root canal, the gray levels were statistically different $(P=0.05)$ from those prior to filling, i.e., the canals did not return to their initial empty state prior to filling with calcium hydroxide. This difference occurred in all thirds, regardless of the technique applied.

To compare the ultrasound and manual techniques, the differences in gray levels after $\mathrm{CH}$ removal and before dressing was evaluated for each third. There was no statistically significant difference $(P>0.05)$ between the techniques (Table 2).

\section{Discussion}

The results of this study showed that neither one of the techniques removed $\mathrm{CH}$ completely. In all thirds, the gray scale values obtained using optical density after the removal of $\mathrm{CH}$ were different from the values obtained after preparation of the empty root canal. These results are similar to the findings of previous studies, which showed considerable amounts of $\mathrm{CH}$ remnants independent of the removal technique used $(9,12,16-18)$.

Despite the excellent antimicrobial characteristics, these remnants of $\mathrm{CH}$ paste can reduce the canal permeability by promoting the formation of calcium carbonate particles and interfering with the sealing ability of endodontic sealers $(7-9,11,19)$. Therefore, different techniques have been proposed to improve the removal of $\mathrm{CH}(16,17,20,21)$.

An irrigant solution in conjunction with ultrasonic vibration was directly associated with the removal of organic and inorganic debris from the root canal walls $(12,16)$.
Thus, the effectiveness of irrigation depends on both the mechanical flushing action and the chemical ability to dissolve tissue $(7,8,21,22)$.

The effect of ultrasonic agitation of the irrigants has been evaluated with contradictory results. In our study, the use of ultrasound did not improve $\mathrm{CH}$ removal from the root canal when compared to the manual technique. In contrast, van der Sluis et al. (16) reported that the use of ultrasound was more efficient than conventional irrigation in removing $\mathrm{CH}$. Wiseman et al. (18) also found better results when using passive ultrasonic irrigation for $\mathrm{CH}$ removal compared to sonic activation. However, it is noteworthy that both authors have reported the persistence of remnants in the canals.

Perhaps the different methods used to assess efficacy may be the reason that some authors report better results with the use of ultrasound. Various methods were applied to evaluate the presence of remnants $(10,18,23,24)$, making it difficult to compare studies regarding evaluation methodologies.

Besides the use of ultrasound, simultaneous factors such as the type of vehicle (oily vehicles are more difficult to remove) $(21)$ and the use of chelating agents $(8,10)$ are important for improving the efficiency of $\mathrm{CH}$ removal. Nevertheless, canal irregularities may be inaccessible for conventional irrigation procedures, and $\mathrm{CH}$ may remain in these extensions $(16,24)$.

\section{Conclusion}

Within the limitations of this study, neither manual nor ultrasonic techniques were able to completely remove calcium hydroxide from the root canals. There were no statistical differences among the thirds analyzed.

Table 1. Comparison of means and standard deviations of the gray levels obtained with ultrasound and manual techniques in the cervical, middle and apical thirds before dressing (BD) and after removal (AR) of calcium hydroxide

\begin{tabular}{lcccccc}
\hline \multirow{2}{*}{ Technique } & \multicolumn{2}{c}{ Cervical } & \multicolumn{2}{c}{ Middle } & \multicolumn{2}{c}{ Apical } \\
\cline { 2 - 7 } & BD & AR & BD & AR & BD & AR \\
\hline Ultrasound $(n=19)$ & $111.35 \pm 27.05$ & $140.44 \pm 17.05$ & $105.74 \pm 25.85$ & $136.95 \pm 16.08$ & $93.14 \pm 26.89$ & $125.44 \pm 12.19$ \\
Manual $(n=19)$ & $111.64 \pm 17.85$ & $135.12 \pm 5.88$ & $104.24 \pm 16.67$ & $130.94 \pm 5.54$ & $93.90 \pm 16.14$ & $118.45 \pm 5.49$ \\
\hline
\end{tabular}

Table 2. Comparison of mean differences and standard deviations of the gray levels obtained with ultrasound and manual techniques in the cervical, middle and apical thirds, before dressing and after removal of calcium hydroxide

\begin{tabular}{lccc}
\hline \multirow{2}{*}{ Technique } & \multicolumn{3}{c}{ Thirds } \\
\cline { 2 - 4 } & Cervical & Middle & Apical \\
\hline Ultrasound $(\mathrm{n}=19)$ & $29.09 \pm 22.21$ & $23.48 \pm 17.22$ & $31.22 \pm 19.17$ \\
Manual $(\mathrm{n}=19)$ & $26.69 \pm 15.15$ & $32.30 \pm 20.31$ & $24.55 \pm 15.59$ \\
$P$ & .065 & .101 & .202 \\
\hline
\end{tabular}


1. Safavi KE, Nichols FC. Effect of calcium hydroxide on bacterial lipopolysaccharide. J Endod 1993;19:76-8.

2. Holland R, de Mello W, Nery MJ, Bernabe PF, de Souza V. Reaction of human periapical tissue to pulp extirpation and immediate root canal filling with calcium hydroxide. J Endod 1977;3:63-7.

3. Çalt $S$, Serper A, Ozcelik B, Dalat MD. pH changes and calcium ion diffusion from calcium hydroxide dressing materials through root dentin. J Endod 1999;25:329-31.

4. Rahde N. de M, Figueiredo JA, Oliveira EP. Influence of calcium hydroxide points on the quality of intracanal dressing filling. J Appl Oral Sci 2006;14:219-23.

5. Simcock RM, Hicks ML. Delivery of calcium hydroxide: comparison of four filling techniques. J Endod 2006;32:680-2.

6. Torres $\mathrm{CP}$, Apicella MJ, Yancich PP, Parker MH. Intracanal placement of calcium hydroxide: a comparison of techniques, revisited. J Endod 2004;30:225-7.

7. Barbizam JV, Trope M, Teixeira EC, Tanomaru-Filho M, Teixeira FB. Effect of calcium hydroxide intracanal dressing on the bond strength of a resin-based endodontic sealer. Braz Dent J 2008;19:224-7.

8. Çalt $S$, Serper A. Dentinal tubule penetration of root canal sealers after root canal dressing with calcium hydroxide. J Endod 1999;25:431-3.

9. Margelos J, Eliades G, Verdelis C, Palaghias G. Interaction of calcium hydroxide with zinc oxide-eugenol type sealers: a potential clinical problem. J Endod 1997;23:43-8.

10. Salgado RJ, Moura-Netto C, Yamazaki AK, Cardoso LN, de Moura AA, Prokopowitsch I. Comparison of different irrigants on calcium hydroxide medication removal: microscopic cleanliness evaluation. Oral Surg Oral Med Oral Pathol Oral Radiol Endod 2009; 107:5804.

11. Böttcher DE, Hirai VHG, Da Silva Neto UX, Grecca FS. Effect of calcium hydroxide dressing on the long-term sealing ability of two different endodontic sealers: An in vitro study. Oral Surg Oral Med Oral Pathol Oral Radiol Endod 2010;1 10:386-9.

12. Kenee DM, Allemang JD, Johnson JD, Hellstein J, Nichol BK. A quantitative assessment of efficacy of various calcium hydroxide removal techniques. J Endod 2006;32:563-5.

13. Alaçam T, Demirtola N, Misirligil A, Ayhan N, Gokay O. In vivo comparison of antimicrobial effectiveness of conventional and ultrasound activated irrigation techniques in root canal therapy. Bull Tokyo Dent Coll 1987;28:19-22.

14. Guerisoli DM, Marchesan MA, Walmsley AD, Lumley PJ, Pecora JD. Evaluation of smear layer removal by EDTAC and sodium hypochlorite with ultrasonic agitation. Int Endod J 2002;35:418-21

15. Serafino C, Gallina G, Cumbo E, Monticelli F, Goracci C, Ferrari M. Ultrasound effects after post space preparation: An SEM study. J Endod 2006;32:549-52.

16. van der Sluis LW, Wu MK, Wesselink PR. The evaluation of removal of calcium hydroxide paste from an artificial standardized groove in the apical root canal using different irrigation methodologies. Int Endod J 2007;40:52-7.

17. Balvedi RP, Versiani MA, Manna FF, Biffi JC. A comparison of two techniques for the removal of calcium hydroxide from root canals. Int Endod J 2010;43:763-8.

18. Wiseman A, Cox TC, Paranipe A, Flake NM, Cohenca N, Johnson JD. Efficacy of sonic and ultrasonic activation for removal of calcium hydroxide from mesial canals of mandibular molars: a microtomographic study. J Endod $2011 ; 37: 235-8$.

19. Ricucci D, Langeland K. Incomplete calcium hydroxide removal from the root canal: a case report. Int Endod J 1997;30:418-21.

20. Naaman A, Kaloustian H, Abboud NN, Ounsi HF, Ricci C, Medioni E. Influence of calcium hydroxide intracanal medication on the sealing ability of warm gutta-percha. Gen Dent 2008;56:348-52.

21. Nandini S, Velmurugan N, Kandaswamy D. Removal efficiency of calcium hydroxide intracanal medicament with two calcium chelators: volumetric analysis using spiral $C T$, an in vitro study. J Endod 2006;32:1097-101.

22. Lee SJ, Wu MK, Wesselink PR. The efficacy of ultrasonic irrigation to remove artificially placed dentine debris from different-sized simulated plastic root canals. Int Endod J 2004;37:607-12.

23. Balvedi RPA, Versiani MA, Manna FF, Biffi JCG. A comparison of two techniques for the removal of calcium hydroxide from root canals. Int Endod J 2010;43:763-8.

24. Rödig T, Hirschleb M, Zapf A, Hülsmann M. Comparison of ultrasonic irrigation and RinsEndo for the removal of calcium hydroxide and Ledermix paste from root canals. Int Endod J 201 1;44:1155-61. 